\title{
Using Bee Products for the Prevention and Treatment of Oral Mucositis Induced by Cancer Treatment
}

\author{
Karsten Münstedt *(D) and Heidrun Männle \\ Department of Gynaecology, Ortenau Klinikum, 77654 Offenburg, Germany \\ * Correspondence: karsten.muenstedt@ortenau-klinikum.de \\ Academic Editor: Lesław Juszczak \\ Received: 9 July 2019; Accepted: 19 August 2019; Published: 21 August 2019
}

\begin{abstract}
Oral mucositis is one of the most frequent complications after chemotherapy or radiotherapy or a combination of both. There is no standard therapy for its prevention or treatment. Considering that some bee products have been found to be of value in this situation, we decided to analyze the scientific literature on the subject. Scientific publications on bee products were identified by a literature search on Pubmed, Scopus and Google Scholar. There is a lot of evidence regarding the use of honey for oral mucositis due to chemotherapy or radiotherapy or a combination of both. Unfortunately, the quality of several meta-analyses on the topic is very low. There is some evidence on propolis, a little on royal jelly and none whatsoever on pollen and other bee products like apilarnil or bee venom. Bee products such as honey, propolis and royal jelly may be well suited to be integrated into a general concept for the prevention and treatment of oral mucositis which should also include other established concepts like oral care, oral cryotherapy, topical vitamin E and low-level-laser therapy. Bee products could become an integral part in the treatment of chemotherapy, radiotherapy and radio chemotherapy. High-quality meta-analyses and further studies, especially on the combinations of various strategies, are needed.
\end{abstract}

Keywords: oral mucositis; chemotherapy; radiotherapy; radio-chemotherapy; honey; propolis; royal jelly

\section{Introduction}

Oral mucositis is one of the most common complications after chemotherapy or local radiotherapy (e.g., for head and neck cancer) or a combination of both. Its severity depends on the type and dose of chemotherapy and/or radiotherapy. Oral mucositis results in erythema and the ulceration of the non-keratinized mucosa, causing significant pain, compromised nutrition, prolonged hospitalization and bloodstream infections. Because of these symptoms, it can cause treatment delays and impact the delivery of optimal cancer treatment, thus affecting clinical remissions and the chances of a cure.

The mechanisms of the development of oral mucositis are not fully understood, especially the specific downstream cellular events resulting in oral epithelial damage. With respect to chemotherapy, the cytotoxic agents will affect all rapidly dividing epithelium along the gastrointestinal tract including the mouth, larynx and pharynx via impaired DNA replication and repair, cell-cycle arrest, DNA damage and cell death. Furthermore, it has been suggested that oral microbiome communities contribute to the development of mucositis [1]. During radiotherapy, reactive oxygen species released from epithelial and endothelial cells will activate NF- $\mathrm{KB}$ and TNF (tumour necrotic factor) producing pro-inflammatory cytokines, influencing ceramide synthase production and causing DNA damage injury and cell death. Once again, bacteria are believed to influence these processes [2]. A detailed and comprehensive review of this topic was recently published by Bowen et al. [3].

In cases of a combination of chemotherapy and radiotherapy, it is believed that the two mechanisms come together, which aggravates the problem. Furthermore, several factors have been found to be 
associated with increased risk for oral mucositis. These include age (increased risk in very young and old age), gender (increased risk in females), oral health and hygiene, low salivary secretory function, genetic factors, body mass index (increased risk in malnourished individuals), poor renal function, smoking and previous cancer treatment [2].

Various methods have been suggested in order to prevent and treat oral mucositis. The German S3-Guideline for supportive care in cancer (a guideline following a systematic development) recommends standardized oral care consisting of a regular application of mouth rinses, dental hygiene (use of a soft toothbrush, use of dental floss), the avoidance of noxious substances (such as alcohol, tobacco, spicy and hot dishes or acidic food), a continuous control of lesions and pain, prophylactic measures by dentists, fluoridation for dental protection and clinical control and counseling during therapy [4].

However, standard oral care alone is not enough for patients receiving such treatments [5]. Unfortunately, there are few other options offered by conventional medicine. A systematic review found that the commonly used chlorhexidine was neither effective in reducing the severity of mucositis nor in preventing its incidence [6]. Concepts primarily come from complementary and integrative medicine. However, the interpretation of the results from various trials is conflicting. For example, one meta-analysis concluded that glutamine may reduce the risk and severity of mucositis during radiotherapy or chemotherapy in general [7], whereas The Mucositis Study Group of the Multinational Association of Supportive Care in Cancer presented a more differentiated conclusion and recommended against parenteral glutamine in hematopoietic stem cell transplantation patients and voted in favor of oral glutamine in head and neck cancer patients [8]. For many other vitamins, minerals and nutritional supplements, no positive recommendations were possible [8]. Low-level-laser therapy has proven its efficacy in a systematic review and meta-analysis [9] but oral cryotherapy is generally recommended, especially when patients receive 5 -fluorouracil chemotherapy $[4,10,11]$.

Little is known on what patients use except for one study from pediatric oncology. Black mulberr, carbonate and honey (11.6\%) were the methods used most frequently [12]. The keratinocyte growth factor may be another interesting option for patients who are receiving either radiotherapy to the head and neck with cisplatin or fluorouracil or chemotherapy alone for mixed solid and hematological cancers [13].

Despite this, the past few years have seen the publication of a considerable number of clinical trials on the use of bee products for oral mucositis with interesting results. Therefore, this review is going to summarize the current evidence of those bee products.

\section{Results}

\subsection{Chemotherapy-Induced Oral Mucositis and Honey}

There is a systematic review on honey for the treatment of chemotherapy-induced mucositis in paediatric oncology patients [14]. It summarizes four papers on the topic and provides Grade C evidence that honey is effective as a preventative and therapeutic measure in paediatric oncology patients. However, two studies not only investigated pure honey. The study by Abdulrhman et al. analyzed honey as well as a combination of honey, olive oil, propolis and beeswax compared to a control group and found that both groups with honey were superior to the control [15]. In less severe cases, honey alone was the best alternative, whereas in more severe cases the combination of honey, olive oil, propolis and beeswax was superior. Another study compared sugar syrup, which was added with some betamethasone to a honey solution, which in turn was added to instant coffee powder and compared to a pure honey group [16]. Interestingly, the combination of honey and coffee was most likely to improve patients' complaints. Additional recent studies confirm the positive effects of honey [17]. However, a trial comparing honey, vitamin $\mathrm{E}$ and chlorhexidine found that vitamin $\mathrm{E}$ was the best alternative [18]. The fact that topical vitamin $\mathrm{E}$ is another interesting option is confirmed in a meta-analysis [19]. 
As mentioned, the evidence for chemotherapy comes from studies in paediatric oncology. However, it seems reasonable to assume that chemotherapy-induced oral mucositis will not differ substantially between children and adults because the underlying pathomechanisms are alike.

One very interesting study combined honey, tulsi (Ocimum tenuiflorum) and cryotherapy and found that the combination is superior to cryotherapy alone [20]. Unfortunately, the authors do not provide details on how the honey-tulsi-ice cubes were made. On one side, it appears that they used honey but on the other side they speak of honey-flavored ice cubes. Unfortunately, the authors Mishra and Nayak have not responded to our request to clarify the information in their paper.

\subsection{Radiotherapy-Induced (Radiation-Induced) Oral Mucositis}

Patients with head and neck cancer mainly depend on radiation therapy in combination with chemotherapy, usually cis-platinum, especially when surgery cannot be done or was unable to remove all the cancer tissue with free margins. Several studies have addressed the question on whether honey may be a means to prevent radiotherapy-induced oral mucositis. These trials have been analyzed by various systematic reviews and even meta-analyses. An overview of trials is given in Table 1. As shown, all trials revealed positive results for honey. Manuka honey was not tested in this situation.

\subsection{Honey and the Combination of Radiotherapy and Chemotherapy}

Unfortunately, there are no trials which have specifically compared the effects of radiotherapy alone to the combination of radiotherapy and chemotherapy on oral mucositis with respect to the protective effects of honey. However, in the systematic review by Münstedt et al. there were nine trials on patients who received a combination of radiotherapy and chemotherapy [29]. Since conventional honey proved to be effective in this situation, it can be recommended here as well. A more recently published trial on the subject confirms the value of honey in this situation 30]. A detailed overview on these trials is given in Table 2. As shown, honey, but not manuka honey, is beneficial. All four trials using manuka honey failed to show an advantage for honey, whereas all trials using conventional honey led to positive results [30]. The reasons for this are unclear but may relate to the unusually high content of methylglyoxal in manuka honey which can be regarded as a cytotoxic agent. Another trial showed that a combination of glycerine plus honey was more effective than the standard treatment [31]. Similarly, a study analyzed the local application of Yashtimadhu (Glycyrrhiza glabra) powder and honey along with oral intake of Yashtimadhu Ghrita versus local application of the Yashtimadhu powder and honey versus local application of honey only or conventional modern medication [32]. It claimed to have found best results for the combination of Yashtimadhu and honey but the results are not convincing because patients were not equally distributed over the four treatment arms and drop-out rates left only nine patients in the honey arm [24]. However, Glycyrrhiza glabra seems to be an interesting option for the treatment of oral mucositis, as shown in another trial [33]. 
Table 1. Summary of randomized trials on honey and radiation therapy. All studies had positive results for honey.

\begin{tabular}{|c|c|c|c|}
\hline $\begin{array}{l}\text { First Author/Year/Jadad } \\
\text { Score }\end{array}$ & Sample; Intervention and Control Group & $\begin{array}{c}\text { Endpoints } \\
(\mathrm{OM}=\text { Oral Mucositis; } \\
\mathrm{QoL}=\text { Quality of Life })\end{array}$ & $\begin{array}{c}\text { Main Results } \\
\text { (OM = Oral Mucositis; } \\
\text { QoL = Quality of Life) }\end{array}$ \\
\hline $\begin{array}{l}\text { Charalambous } 2018 \text { [21] } \\
3\end{array}$ & $\begin{array}{l}86 \text { patients } \\
\text { Group 1: } 43 \text { patients with diluted thyme } \\
\text { honey }(20 \mathrm{~mL} \text { of thyme honey in } 100 \mathrm{~mL} \\
\text { water making gargles in the oral cavity-1/4 } \\
\text { h before and after radiotherapy and } 6 \mathrm{~h} \\
\text { later) } \\
\text { Group 2: } 43 \text { patients with saline } 0.9 \%\end{array}$ & $\begin{array}{ll}\text { - } & \text { OM grade } \\
\text { - } & \text { Weight loss } \\
\text { - Oral problems (i.e., } \\
\text { swallowing, drinking, eating, } \\
\text { mouth and throat pain) } \\
\text { - QoL }\end{array}$ & $\begin{array}{l}\text { - } \quad \text { Lower grades of OM } \\
\text { - } \quad \text { Better maintenance of } \\
\text { body weight } \\
\text { - } \quad \text { Improvement in global health } \\
\text { - } \quad \begin{array}{l}\text { No study discontinuation } \\
\text { because of honey }\end{array}\end{array}$ \\
\hline $\begin{array}{l}\text { Amanat } 2017[22] \\
3\end{array}$ & $\begin{array}{l}82 \text { patients } \\
\text { Group 1: } 41 \text { patients with ziziphus honey } \\
\text { ( } 20 \mathrm{~mL}-1 / 4 \mathrm{~h} \text { before and after the } \\
\text { radiotherapy) } \\
\text { Group 2: } 25 \text { patients with saline } 0.9 \%\end{array}$ & - $\quad$ OM grade & $\begin{array}{l}\text { - Lower grades of OM in the } \\
\text { honey group } \\
\text { No study discontinuation } \\
\text { because of honey }\end{array}$ \\
\hline $\begin{array}{c}\text { Bahramnezhad } 2015 \text { [23] } \\
0\end{array}$ & $\begin{array}{l}105 \text { patients } \\
\text { Group 1: } 35 \text { patients with diluted polyfloral } \\
\text { honey ( } 50 \mathrm{~mL} \text { honey and } 25 \mathrm{~mL} \\
\text { water-administration schedule not given) } \\
\text { Group 2: } 35 \text { patients with water } \\
\text { Group 3: } 35 \text { patients with water } \\
\text { chamomile }\end{array}$ & - $\quad$ OM grade & $\begin{array}{l}\text { - Lowest grades of OM in the } \\
\text { honey group } \\
\text { No study discontinuation } \\
\text { because of honey }\end{array}$ \\
\hline $\begin{array}{l}\text { Alvi } 2013[24] \\
2\end{array}$ & $\begin{array}{l}60 \text { patients } \\
\text { Group 1: } 30 \text { patients with polyfloral honey } \\
(20 \mathrm{~mL}-1 / 4 \mathrm{~h} \text { before and after radiotherapy } \\
\text { and } 6 \mathrm{~h} \text { later) } \\
\text { Group 2: } 30 \text { patients with saline } 0.9 \%\end{array}$ & $\begin{array}{ll}\text { - } & \text { OM grade } \\
\text { - } & \text { Weight loss } \\
\text { - } & \text { Treatment discontinuation }\end{array}$ & $\begin{array}{ll}\text { - } & \text { Lower grades of OM } \\
\text { Better maintenance of } \\
\text { body weight } \\
\text { - } \quad \text { No study discontinuation } \\
\text { because of honey in the } \\
\text { honey group } \\
\text { - No discontinuation of } \\
\text { radiotherapy in the honey } \\
\text { group (0 vs. } 3 \text { in the } \\
\text { control group) }\end{array}$ \\
\hline $\begin{array}{c}\text { Jayachandran }[25] \\
2012 \\
2\end{array}$ & $\begin{array}{l}60 \text { patients } \\
\text { Group 1: } 20 \text { patients with polyfloral honey } \\
(20 \mathrm{~mL}-1 / 4 \mathrm{~h} \text { before and after radiotherapy } \\
\text { and } 6 \mathrm{~h} \text { later) } \\
\text { Group 2: } 20 \text { patients with benzydamine } \\
\text { hydrochloride } \\
\text { Group 3: } 20 \text { patients with saline } 0.9 \%\end{array}$ & $\begin{array}{ll}- & \text { OM grade } \\
- & \text { Onset of OM } \\
\text { - } & \text { Recovery after end of therapy }\end{array}$ & $\begin{array}{ll}\text { - } & \text { Later onset of OM } \\
\text { - } & \text { Lower grades of OM } \\
\text { during radiotherapy } \\
\text { - } \quad \text { Faster recovery from OM after } \\
\text { the end of radiotherapy in the } \\
\text { honey group } \\
\text { - No study discontinuation } \\
\text { because of honey }\end{array}$ \\
\hline $\begin{array}{l}\text { Khanal } 2010[26] \\
2\end{array}$ & $\begin{array}{l}40 \text { patients } \\
\text { Group 1: } 20 \text { patients with polyfloral honey } \\
\text { ( } 20 \mathrm{~mL}-1 / 4 \mathrm{~h} \text { before and after radiotherapy } \\
\text { and before going to bed) } \\
\text { Group 2: } 20 \text { patients with lignocaine } \\
\text { Gel }\end{array}$ & $\begin{array}{l}-\quad \text { OM grade } \\
-\quad \text { Pain associated with OM }\end{array}$ & $\begin{array}{l}\text { - } \quad \text { Lower grades of OM } \\
\text { - } \quad \text { Less pain in the honey group } \\
\text { because of honey }\end{array}$ \\
\hline $\begin{array}{l}\text { Motallebnejad } 2008 \text { [27] } \\
2\end{array}$ & $\begin{array}{l}40 \text { patients } \\
\text { Group 1: } 20 \text { patients with thyme and } \\
\text { astragal honey }(20 \mathrm{~mL}-1 / 4 \mathrm{~h} \text { before and } \\
\text { after radiotherapy and } 6 \mathrm{~h} \text { later }) \\
\text { Group 2: } 20 \text { patients with saline } 0.9 \%\end{array}$ & $\begin{array}{ll}- & \text { OM grade } \\
\text { - } & \text { Weight loss }\end{array}$ & $\begin{array}{ll}\text { - } & \text { Lower grades of OM } \\
\text { - } & \text { Better maintenance of } \\
\text { body weight } \\
\text { - } \quad \text { in the honey group } \\
\text { - } \quad 4 \text { patients in the honey group } \\
\text { with Grade 0 OM } \\
\text { discontinued treatment }\end{array}$ \\
\hline $\begin{array}{l}\text { Biswal } 2003[28] \\
2\end{array}$ & $\begin{array}{l}40 \text { patients } \\
\text { Group 1: } 20 \text { patients with tea plant honey } \\
(20 \mathrm{~mL}-1 / 4 \mathrm{~h} \text { before and after radiotherapy } \\
\text { and } 6 \mathrm{~h} \text { later) } \\
\text { Group 2: } 20 \text { patients with saline } 0.9 \%\end{array}$ & $\begin{array}{ll}\text { - } & \text { OM grade } \\
\text { - } & \text { Weight loss } \\
\text { - } & \text { Treatment discontinuation } \\
& \text { Duration of mucositis }\end{array}$ & $\begin{array}{l}\text { - } \quad \text { Lower percentage of patients } \\
\text { with grade } 3 / 4 \text { mucositis } \\
\text { Better maintenance of } \\
\text { body weight } \\
\text { - } \quad \text { in the honey group } \\
\text { - No discontinuation of } \\
\text { radiotherapy in the honey } \\
\text { group }(0 \% \text { vs. } 20 \% \text { in the } \\
\text { control group) } \\
\text { - } \quad \begin{array}{l}\text { Duration of mucositis }=\text { n.s. } \\
\text { - }\end{array} \\
\text { discoport of study } \\
\text { of honey }\end{array}$ \\
\hline
\end{tabular}


Table 2. Summary of randomized trials on honey and the combination of chemotherapy and radiation therapy. (Studies highlighted in green mean positive results for honey, studies highlighted in red mean negative results for honey.) Note: All studies on manuka honey had negative results.

\begin{tabular}{|c|c|c|c|}
\hline $\begin{array}{l}\text { First Author } / \text { Year/Jadad } \\
\text { Score }\end{array}$ & Sample; Intervention and Control Group & $\begin{array}{c}\text { Endpoints } \\
(\mathrm{OM}=\text { Oral Mucositis; } \\
\mathrm{QoL}=\text { Quality of Life })\end{array}$ & $\begin{array}{c}\text { Main Results } \\
\text { (OM = Oral Mucositis; } \\
\text { QoL= Quality of Life) }\end{array}$ \\
\hline $\begin{array}{l}\text { Howlader } 2019 \text { [30] } \\
1\end{array}$ & $\begin{array}{l}40 \text { patients } \\
\text { Group 1: } 20 \text { patients with } 20 \mathrm{~mL} \text { polyfloral } \\
\text { honey } 1 / 4 \mathrm{~h} \text { prior to radiation, and } 1 / 4 \mathrm{~h} \text { and } \\
6 \mathrm{~h} \text { after radiation } \\
\text { Group 2: } 20 \text { patients rinse with saline } 1 / 4 \mathrm{~h} \\
\text { before and } 1 / 4 \mathrm{~h} \text { after radiation exposure }\end{array}$ & $\begin{array}{ll}\text { - } & \text { OM grade } \\
\text { - } & \text { QoL }\end{array}$ & $\begin{array}{l}\text { - Lower grades of OM at the end } \\
\text { of treatment } \\
\text { - } \quad \text { Better quality of life } \\
\text { - } \quad \text { in the honey group }\end{array}$ \\
\hline $\begin{array}{c}\text { Rao } 2017[34] \\
2\end{array}$ & $\begin{array}{l}50 \text { patients } \\
\text { Group 1: } 25 \text { patients with polyfloral honey } \\
\text { (exact quantity not given }-1 \mathrm{~h} \text { prior to } \\
\text { radiation, and } 2 \text { and } 6 \mathrm{~h} \text { after radiation) } \\
\text { Group 2: } 25 \text { patients with povidone-iodine }\end{array}$ & $\begin{array}{l}\text { - } \quad \text { OM grade } \\
\text { - } \quad \text { Treatment interruptions } \\
\text { - Tumour response }\end{array}$ & $\begin{array}{l}\text { - } \quad \text { Lower grades of OM } \\
\text { Better maintenance of } \\
\text { body weight } \\
\text { - Fewer treatment interruptions } \\
\text { in the honey group } \\
\text { - Honey has no effect on } \\
\text { tumour response } \\
\text { - No study discontinuation } \\
\text { because of honey }\end{array}$ \\
\hline $\begin{array}{c}\text { Fogh } 2017[35] \\
3\end{array}$ & $\begin{array}{l}163 \text { patients } \\
\text { Group 1: } 53 \text { patients with supportive } \\
\text { careGroup 2: } 54 \text { patients with manuka } \\
\text { honey ( } 10 \mathrm{~mL}-\text { lozenges } 4 \text { times per day, } \\
\text { over a period of } 12 \mathrm{~h} \text { daily) } \\
\text { Group } 3: 56 \text { patients with lozenge manuka } \\
\text { honey ( } 2 \text { lozenges } 4 \text { timesper day, over a } \\
\text { period of } 12 \mathrm{~h} \text { daily) }\end{array}$ & $\begin{array}{ll}\text { - } & \text { Pain on swallowing } \\
\text { - } & \text { QoL } \\
\text { - } & \text { Secondary endpoints } \\
\text { - } & \text { Opiover time } \\
\text { - } & \text { Clinically graded and } \\
& \text { patient-reported } \\
\text { adverse events } \\
\text { - } & \text { Weight loss } \\
\text { - } & \text { Dysphagia } \\
\text { - Nutritional status, }\end{array}$ & $\begin{array}{l}\text { - No significant difference in the } \\
\text { primary endpoint } \\
\text { No differences in any of the } \\
\text { secondary endpoints except for } \\
\text { opioid use } \\
\text { - More patients on the } \\
\text { supportive care arm } \\
\text { took opioids }\end{array}$ \\
\hline $\begin{array}{c}\text { Jayalekshmi } 2016 \text { [36] } \\
3\end{array}$ & $\begin{array}{l}28 \text { patients } \\
\text { Group } 1: 14 \text { patients with polyfloral honey } \\
(15 \mathrm{~mL}-1 / 4 \mathrm{~h} \text { before and after radiotherapy } \\
\text { and } 6 \mathrm{~h} \text { later }) \\
\text { Group 2: } 14 \text { patients with water }\end{array}$ & - $\quad$ OM grade & $\begin{array}{l}\text { - Lower grades of OM in the } \\
\text { honey group } \\
\text { No study discontinuation } \\
\text { because of honey }\end{array}$ \\
\hline $\begin{array}{l}\text { Samdariya2015 [37] } \\
3\end{array}$ & $\begin{array}{l}78 \text { patients } \\
\text { Group 1: } 40 \text { patients with polyfloral honey } \\
(20 \mathrm{~mL}-1 / 4 \mathrm{~h} \text { before and after radiotherapy } \\
\text { and } 6 \mathrm{~h} \text { later }) \text { and salt-soda and } \\
\text { benzydamine gargle } \\
\text { Group 2: } 38 \text { patients with salt-soda and } \\
\text { benzydamine gargle }\end{array}$ & - $\quad$ Pain & $\begin{array}{l}\text { - Less pain in the honey group } \\
\text { - No study discontinuation } \\
\text { because of honey }\end{array}$ \\
\hline $\begin{array}{l}\text { Hawley } 2014[38] \\
5\end{array}$ & $\begin{array}{l}106 \text { patients } \\
\text { Group 1: } 54 \text { patients with manuka honey } \\
\text { (5-mL -four times a day after radiotherapy } \\
\text { and after meals) } \\
\text { Group 2: } 52 \text { patients with placebo gel }\end{array}$ & - OM grade & $\begin{array}{l}\text { - No significant difference in the } \\
\text { primary endpoint } \\
\text { High dropout rates } 57 \% \text { in the } \\
\text { honey group vs. } 52 \% \text { in the } \\
\text { control group n.s. }\end{array}$ \\
\hline $\begin{array}{l}\text { Maiti } 2012[39] \\
1\end{array}$ & $\begin{array}{l}55 \text { patients } \\
\text { Group 1: } 28 \text { patients with polyfloral honey } \\
(20 \mathrm{~mL}-1 / 4 \mathrm{~h} \text { before and after radiotherapy } \\
\text { and } 6 \mathrm{~h} \text { later }) \\
\text { Group 2: } 27 \text { patients no additional } \\
\text { treatment }\end{array}$ & $\begin{array}{l}\text { - } \quad \text { OM grade } \\
\text { - Weight loss }\end{array}$ & $\begin{array}{l}\text { - Lower grades of OM, } \\
\text { - } \text { Better maintenance of body } \\
\text { - Neight in the honey group } \\
\text { No study discontinuation } \\
\text { because of honey }\end{array}$ \\
\hline $\begin{array}{c}\text { Bardy } 2012[40] \\
5\end{array}$ & $\begin{array}{l}131 \text { patients } \\
\text { Group 1: } 67 \text { patients with manuka honey } \\
\text { ( } 20 \mathrm{~mL}-4 \text { times a day) } \\
\text { Group 2: } 64 \text { patients with golden syrup }\end{array}$ & $\begin{array}{l}\text { - } \text { OM grade } \\
\text { - } \\
\text { - Secondary aims } \\
\text { - } \\
\text { assessment of microbiological } \\
\text { - } \quad \text { requ in the mouth, } \\
\text { drugs and analgesia } \\
\text { - } \quad \text { Neight loss } \\
\text { - Need for tube feeding }\end{array}$ & $\begin{array}{l}\text { - No significant differences in } \\
\text { the primary and } \\
\text { secondary endpoints } \\
\text { No differences in } \\
\text { patients' compliance }\end{array}$ \\
\hline
\end{tabular}


Table 2. Cont.

\begin{tabular}{|c|c|c|c|}
\hline $\begin{array}{l}\text { First Author } / \text { Year } / \text { Jadad } \\
\text { Score }\end{array}$ & Sample; Intervention and Control Group & $\begin{array}{c}\text { Endpoints } \\
(\mathrm{OM}=\text { Oral Mucositis; } \\
\text { QoL = Quality of Life })\end{array}$ & $\begin{array}{c}\text { Main Results } \\
\text { (OM = Oral Mucositis; } \\
\text { QoL= Quality of Life) }\end{array}$ \\
\hline $\begin{array}{c}\text { Parsons } 2012[41] \\
1\end{array}$ & $\begin{array}{l}28 \text { patients } \\
\text { Group } 1: 6 \text { patients with manuka honey ( } 20 \\
\mathrm{~mL}-1 / 4 \mathrm{~h} \text { before and after radiotherapy } \\
\text { and } 6 \mathrm{~h} \text { later) } \\
\text { Group } 2: 12 \text { patients with diluted manuka } \\
\text { honey }(10 \mathrm{~mL} \text { in } 30 \mathrm{~mL} \text { of water-1/4 } \mathrm{h} \\
\text { before and after radiotherapy and } 6 \mathrm{~h} \text { later }) \\
\text { Group } 3: 10 \text { patients receiving standard care }\end{array}$ & $\begin{array}{ll}\text { - } & \text { OM grade } \\
\text { - } & \text { Weight loss } \\
\text { - } & \text { QoL }\end{array}$ & $\begin{array}{l}\text { - No significant difference } \\
\text { regarding OM grade } \\
\text { Better maintenance of body } \\
\text { weight in the honey group } \\
\text { Diluted manuka honey } \\
\text { increased overall QoL in the } \\
\text { radiotherapy group but not in } \\
\text { group of radiotherapy in } \\
\text { combination } \\
\text { with chemotherapy } \\
\text { 6/6 patients in the honey group, } \\
2 / 12 \text { in the diluted honey group } \\
\text { and } 2 / 10 \text { in the control group } \\
\text { withdrew from the study } \\
\text { because of pain and nausea }\end{array}$ \\
\hline $\begin{array}{l}\text { Rashad } 2009[42] \\
2\end{array}$ & $\begin{array}{l}40 \text { patients } \\
\text { Group 1: } 20 \text { patients with clover honey }(20 \\
\mathrm{mL}-1 / 4 \mathrm{~h} \text { before and after radiotherapy } \\
\text { and } 6 \mathrm{~h} \text { later) } \\
\text { Group 2: } 20 \text { patients receiving standard care }\end{array}$ & $\begin{array}{l}\text { - OM grade } \\
\text { assessment of microbiological } \\
\text { flora in the mouth }\end{array}$ & $\begin{array}{l}\text { - Lower grades of OM } \\
\text { Lower rates of pathogenic } \\
\text { bacteria and fungi in the } \\
\text { honey group }\end{array}$ \\
\hline
\end{tabular}

\subsection{Working Mechanisms of Honey}

Unfortunately, there are no studies which have investigated the working mechanisms of honey in oral mucositis. However, it has been shown that honey could influence aspects in the pathogenesis of oral mucositis. Since it was shown that pathogens, especially bacteria, could play a role in oral mucositis, the antibacterial properties of honey could be beneficial [43]. Since wounds due to radiotherapy have been found to be very similar to burns, honey's antimicrobial and anti-inflammatory properties, its ability to autolytically debride and deodorize and its ability to stimulate tissue growth and to manage pain and minimize scarring are likely to be helpful as well [44,45].

\subsection{Propolis and Radiotherapy}

Evidence regarding the usefulness of propolis in radiotherapy dates back to 1989, when it was shown that both water and alcohol-based propolis extracts reduce radiotherapy-induced/radiation-induced mucositis and its associated swellings. Thus, the scheduled completions of radiotherapy were higher due to the intervention of propolis [46,47]. Another small, more recent, study on the topic determined the beneficial effects of propolis in comparison to control (water) [48]. Meanwhile, another study has confirmed that propolis efficiently prevents and heals radiation-induced mucositis [49]. As mentioned before, the study by Abdulrhman et al. analyzed a combination of honey, olive oil, propolis and beeswax and found that in more severe cases this combination was superior to honey and a control group [15]. This calls for further research on the benefit of propolis alone versus the benefit of a honey-propolis combination.

It was also shown that propolis leads to less DNA damage in healthy cells which could explain part of its preventive effect [50]. Another mechanism could be its antibiotic effect against bacteria and viruses [51,52].

\subsection{Propolis and Chemotherapy}

The first investigation on the subject found no evidence for the benefit of propolis but found a $6 \%$ difference in favor of propolis [53]. This study only comprised 40 patients and the small number of patients may have been the reason why the level of significance was not reached. Further studies showed that propolis was superior to placebo or control groups [49,54-56]. 


\subsection{Royal Jelly and Chemotherapy-Induced Oral Mucositis}

After an in vivo animal trial showed wounds induced by chemotherapy healing faster with a royal jelly containing chitosan-sodiumalginate-film, clinical trials were initiated [57]. The first trial, comprising of 103 patients, investigated royal jelly in combination with antiphlogistic and antifungal treatments for the treatment of oral mucositis [58]. In comparison to controls and depending on the severity of mucositis, healing was significantly faster with royal jelly (up to 6.5 days). Another small trial of 13 patients also provided some evidence for its usefulness in this clinical setting [59].

\subsection{Pollen and Other Bee Products}

There are no studies yet which have used bee pollen as a means to prevent or treat oral mucositis. However, studies on date palm pollen suggest a potential benefit [60]. There are no studies on other bee products such as apilarnil or bee venom on the subject.

\section{Discussion}

The presented data show that some bee products (honey, propolis, royal jelly and pollen) may be interesting candidates for the prevention and treatment of oral mucositis due to chemotherapy or radiotherapy or a combination of both. Clearly, the evidence regarding honey and radiation-induced oral mucositis is strongest [29]. The finding of the mentioned systematic review that conventional honey, but not manuka honey, seems to be a good treatment option cautions us to generalize the positive effects of all types of honeys and reminds us that all bee products do not have uniform properties. According to most studies patients should receive about $20 \mathrm{~mL} 15 \mathrm{~min}$ before and after radiotherapy and a third dose $6 \mathrm{~h}$ later. In the case of propolis, different plant sources as well as different extraction methods may result in different medicinal properties [61]. Thus, it seems important that the relevant substances and production methods of bee products in clinical trials are clearly specified. Furthermore, it is important to note that some trials used diluted bee products or combinations of bee products with other substances which might result in negative results [62]. Adverse interactions are possible. However, the efficacy of honey may be improved by the addition of effective substances or new ways of administration, e.g., honey cryotherapy.

For incomprehensible reasons, several meta-analyses had great methodological flaws and mixed up studies on radiotherapy- or chemotherapy-induced mucositis, or analysed studies were not only on bee products but plant extracts or only honey flavoured products [63-68]. The problems of these meta-analyses have been described in greater detail elsewhere [29,69]. If bee products should become part of the treatment concept for oral mucositis, it is important that the systematic reviews and meta-analyses are done properly.

Apart from the analyses on efficacy regarding the prevention and treatment of oral mucositis, it must be noted that propolis is a substance with many pharmacologically active molecules and that there is a chance that propolis may interfere with chemotherapy, e.g., bleomycin [70,71]. Such drug interactions could lead to the impaired efficacy of chemotherapy, which must be avoided. In this respect, it must be ascertained whether the efficacy of the basic treatment is compromised or not. This should also be a matter of future investigations.

Regarding the potential use of bee products in this area and acknowledging that the complementary and integrative measures for the prophylaxis and treatment of oral mucositis should be effective, safe, cost effective and readily available, algorithms can be established. Consideration of the named factors seems to be appropriate in order to provide the best care to the patient. Since direct comparisons between the various treatment options are scarce, the strength of these suggestions is still limited. Based on the findings of this review and the above-mentioned concept, the following approaches can be suggested (Tables 3-6). The number of pluses indicates the strength of evidence $(+++=$ very good evidence; $++=$ good evidence; $+=$ some evidence). 
Table 3. Suggestions regarding prophylaxis of chemotherapy-induced oral mucositis.

\begin{tabular}{ccc}
\hline Method & Effectiveness & Safety \\
\hline Oral care & +++ & +++ \\
\hline Oral cryotherapy & +++ & +++ \\
\hline Honey & ++ & ++ \\
\hline Topical vitamin E & +++ & +++ \\
\hline Low-level-laser therapy & +++ & +++ \\
\hline Glutamine & ++ & ++ \\
\hline Propolis & ++ & ++ \\
\hline
\end{tabular}

Table 4. Suggestions regarding treatment of chemotherapy-induced oral mucositis.

\begin{tabular}{ccc}
\hline Method & Effectiveness & Safety \\
\hline Oral care & + & + \\
\hline Honey & ++ & ++ \\
\hline Topical vitamin E & +++ & +++ \\
\hline Low-level-laser therapy & +++ & +++ \\
\hline Royal jelly & + & + \\
\hline
\end{tabular}

Table 5. Suggestions regarding prophylaxis of radiation-induced oral mucositis.

\begin{tabular}{ccc}
\hline Method & Effectiveness & Safety \\
\hline Oral care & +++ & +++ \\
\hline Honey & +++ & +++ \\
\hline Topical vitamin E & +++ & +++ \\
\hline Low-level-laser therapy & ++ & ++ \\
\hline Glutamine & ++ & ++ \\
\hline
\end{tabular}

Table 6. Suggestions regarding treatment of radiation-induced oral mucositis.

\begin{tabular}{ccc}
\hline Method & Effectiveness & Safety \\
\hline Oral care & +++ & +++ \\
\hline Honey & +++ & +++ \\
\hline Topical vitamin E & +++ & +++ \\
\hline Low-level-laser therapy & ++ & ++ \\
\hline Royal jelly & + & + \\
\hline
\end{tabular}

While cryotherapy, oral care, topical vitamin E and low-level-laser therapy can be used without risk, it must be remembered that royal jelly and propolis have some allergic potential, so decisions regarding their use must be made very carefully and with specific patient information.

The use of honey ice cubes, as mentioned by Mishra and Nayak, deserves further attention because it combines two interesting treatment options [20]. Furthermore, it seems important that not only single treatments, but sequential treatment concepts are investigated, i.e., oral care as a basis, cyrotherapy during the infusion of cytotoxic drugs, honey during the days after chemotherapy and during radiotherapy instead of honey alone. Further high-quality research is necessary to further improve the standards of oncological care. 


\section{Materials and Methods}

Scientific publications on bee products were identified by a literature search on Pubmed, Scopus and Google Scholar. All publications which seemed appropriate for this review were read in full-text form.

\section{Conclusions}

The use of the bee products honey and propolis seems to be very appropriate for the prophylaxis and treatment of oral mucositis induced by radiotherapy, chemotherapy and a combination of both. Further studies on co-administered methods and the best sequences are necessary.

Author Contributions: Both authors contributed equally to this publication.

Funding: This research received no external funding.

Conflicts of Interest: The authors declare no conflict of interest except that both authors are hobby beekeepers.

\section{References}

1. Hong, B.Y.; Sobue, T.; Choquette, L.; Dupuy, A.K.; Thompson, A.; Burleson, J.A.; Salner, A.L.; Schauer, P.K.; Joshi, P.; Fox, E.; et al. Chemotherapy-induced oral mucositis is associated with detrimental bacterial dysbiosis. Microbiome 2019, 7, 66. [CrossRef] [PubMed]

2. Maria, O.M.; Eliopoulos, N.; Muanza, T. Radiation-induced oral mucositis. Front. Oncol. 2017, 7, 89. [CrossRef] [PubMed]

3. Bowen, J.; Al-Dasooqi, N.; Bossi, P.; Wardill, H.; Van Sebille, Y.; Al-Azri, A.; Bateman, E.; Correa, M.E.; Raber-Durlacher, J.; Kandwal, A.; et al. Mucositis Study Group of the Multinational Association of Supportive Care in Cancer/International Society of Oral Oncology (MASCC/ISOO). The pathogenesis of mucositis: Updated perspectives and emerging targets. Support. Care Cancer 2013, 21, 2075-2083. [CrossRef]

4. S3-Leitlinie Supportive Therapie bei onkologischen PatientInnen. Available online: www.awmf.org/uploads/ tx_szleitlinien/032-054OL1_S3_Supportiv_2017-05.pdf (accessed on 14 June 2019).

5. Peng, H.; Chen, B.B.; Chen, L.; Chen, Y.P.; Liu, X.; Tang, L.L.; Mao, Y.P.; Li, W.F.; Zhang, Y.; Lin, A.H.; et al. A network meta-analysis in comparing prophylactic treatments of radiotherapy-induced oral mucositis for patients with head and neck cancers receiving radiotherapy. Oral Oncol. 2017, 75, 89-94. [CrossRef] [PubMed]

6. Cardona, A.; Balouch, A.; Abdul, M.M.; Sedghizadeh, P.P.; Enciso, R. Efficacy of chlorhexidine for the prevention and treatment of oral mucositis in cancer patients: A systematic review with meta-analyses. $J$. Oral. Pathol. Med. 2017, 46, 680-688. [CrossRef] [PubMed]

7. Leung, H.W.; Chan, A.L. Glutamine in alleviation of radiation-induced severe oral mucositis: A meta-analysis. Nutr. Cancer 2016, 68, 734-742. [CrossRef] [PubMed]

8. Yarom, N.; Hovan, A.; Bossi, P.; Ariyawardana, A.; Jensen, S.B.; Gobbo, M.; Saca-Hazboun, H.; Kandwal, A.; Majorana, A.; Ottaviani, G.; et al. Mucositis Study Group of the Multinational Association of Supportive Care in Cancer/International Society of Oral Oncology (MASCC/ISOO). Systematic review of natural and miscellaneous agents for the management of oral mucositis in cancer patients and clinical practice guidelines-part 1: Vitamins, minerals, and nutritional supplements. Support. Care Cancer 2019. [CrossRef]

9. He, M.; Zhang, B.; Shen, N.; Wu, N.; Sun, J. A systematic review and meta-analysis of the effect of low-level laser therapy (LLLT) on chemotherapy-induced oral mucositis in pediatric and young patients. Eur. J. Pediatr. 2018, 177, 7-17. [CrossRef]

10. Wang, L.; Gu, Z.; Zhai, R.; Zhao, S.; Luo, L.; Li, D.; Zhao, X.; Wei, H.; Pang, Z.; Wang, L.; et al. Efficacy of oral cryotherapy on oral mucositis prevention in patients with hematological malignancies undergoing hematopoietic stem cell transplantation: A meta-analysis of randomized controlled trials. PLoS ONE 2015, 10, e0128763. [CrossRef] [PubMed]

11. Manzi Nde, M.; Silveira, R.C.; dos Reis, P.E. Prophylaxis for mucositis induced by ambulatory chemotherapy: Systematic review. J. Adv. Nurs. 2016, 72, 735-746. [CrossRef] [PubMed]

12. Osmanoglu Yurdakul, Z.; Esenay, F.I. Complementary and integrative health methods used for the treatment of oral mucositis in children with cancer in Turkey. J. Spec. Pediatr. Nurs. 2019, 24, e12260. [CrossRef] [PubMed] 
13. Riley, P.; Glenny, A.M.; Worthington, H.V.; Littlewood, A.; Fernandez Mauleffinch, L.M.; Clarkson, J.E.; McCabe, M.G. Interventions for preventing oral mucositis in patients with cancer receiving treatment: cytokines and growth factors. Cochrane Database Syst. Rev. 2017, 11, CD011990. [CrossRef] [PubMed]

14. Friend, A.; Rubagumya, F.; Cartledge, P. Global Health Journal Club: Is honey effective as a treatment for chemotherapy-induced mucositis in pediatric oncology patients? J. Trop. Pediatr. 2018, 64, 162-168. [CrossRef] [PubMed]

15. Abdulrhman, M.; Elbarbary, N.S.; Ahmed Amin, D.; Saeid Ebrahim, R. Honey and a mixture of honey, beeswax, and olive oil-propolis extract in treatment of chemotherapy-induced oral mucositis: A randomized controlled pilot study. Pediatr. Hematol. Oncol. 2012, 9, 285-292. [CrossRef] [PubMed]

16. Raeessi, M.A.; Raeessi, N.; Panahi, Y.; Gharaie, H.; Davoudi, S.M.; Saadat, A.; Karimi Zarchi, A.A.; Raeessi, F.; Ahmadi, S.M.; Jalalian, H. "Coffee plus honey" versus "topical steroid" in the treatment of chemotherapy-induced oral mucositis: a randomised controlled trial. BMC Complement. Altern. Med. 2014, 14, 293. [CrossRef] [PubMed]

17. Singh, R.; Sharma, S.; Kaur, S.; Medhi, B.; Trehan, A.; Bijarania, S.K. Effectiveness of topical application of honey on oral mucosa of children for the management of oral mucositis associated with chemotherapy. Indian J. Pediatr. 2019, 86, 224-228. [CrossRef] [PubMed]

18. Konuk Sener, D.; Aydin, M.; Cangur, S.; Guven, E. The effect of oral care with chlorhexidine; vitamin E and honey on mucositis in paediatric intensive care patients: A randomized controlled trial. J. Pediatr. Nurs. 2019, 45, e95-e101. [CrossRef]

19. Chaitanya, N.C.; Muthukrishnan, A.; Babu, D.B.G.; Kumari, C.S.; Lakshmi, M.A.; Palat, G.; Alam, K.S. Role of vitamin $\mathrm{E}$ and vitamin $\mathrm{A}$ in oral mucositis induced by cancer chemo/radiotherapy-A meta-analysis. J. Clin. Diagn. Res. 2017, 11, ZE06-ZE09. [CrossRef] [PubMed]

20. Mishra, L.; Nayak, G. Effect of flavored (honey and tulsi) ice chips on reduction of oral mucositis among children receiving chemotherapy. Int. J. Pharm. Sci. Rev. Res. 2017, 43, 25-28.

21. Charalambous, M.; Raftopoulos, V.; Paikousis, L.; Katodritis, N.; Lambrinou, E.; Vomvas, D.; Georgiou, M.; Charalambous, A. The effect of the use of thyme honey in minimizing radiation-induced oral mucositis in head and neck cancer patients: a randomized controlled trial. Eur. J. Oncol. Nurs. 2018, 34, 89-97. [CrossRef]

22. Amanat, A.; Ahmed, A.; Kazmi, A.; Aziz, B. The effect of honey on radiation-induced oral mucositis in head and neck cancer patients. Indian J. Palliat. Care 2017, 23, 317-320. [CrossRef] [PubMed]

23. Bahramnezhad, F.; Dehghan Nayeri, N.; Bassampour, S.S.; Khajeh, M.; Asgari, P. Honey and radiation-induced stomatitis in patients with head and neck cancer. Iran. Red Crescent Med. J. 2015, 17, e19256. [CrossRef]

24. Alvi, Z.A.; Mahmood, A.; Rasul, S.; Ali, U.; Arif, S.; Ishtiaq, S.; Maqsoo, T. Role of honey in prevention of radiation induced mucositis in head and neck cancer. Pak. Armed Forces Med. J. 2013, 63, 379-383. [CrossRef]

25. Jayachandran, S.; Balaji, N. Evaluating the effectiveness of topical application of natural honey and benzydamine hydrochloride in the management of radiation mucositis. Indian J. Palliat. Care 2012, 18, 190-195. [PubMed]

26. Khanal, B.; Baliga, M.; Uppal, N. Effect of topical honey on limitation of radiation-induced oral mucositis: an intervention study. Int. J. Oral. Maxillofac. Surg. 2010, 39, 1181-1185. [CrossRef] [PubMed]

27. Motallebnejad, M.; Akram, S.; Moghadamnia, A.; Moulana, Z.; Omidi, S. The effect of topical application of pure honey on radiation-induced mucositis: a randomized clinical trial. J. Contemp. Dent. Pract. 2008, 9, 40-47. [CrossRef] [PubMed]

28. Biswal, B.M.; Zakaria, A.; Ahmad, N.M. Topical application of honey in the management of radiation mucositis: a preliminary study. Support. Care Cancer 2003, 11, 242-248. [PubMed]

29. Münstedt, K.; Momm, F.; Hübner, J. Honey in the management of side effects of radiotherapy- or radio/chemotherapy-induced oral mucositis. A systematic review. Complement. Ther. Clin. Pract. 2019, 34, 145-152. [CrossRef]

30. Howlader, D.; Singh, V.; Mohammad, S.; Gupta, S.; Pal, U.S.; Pal, M. Effect of topical application of pure honey in chemo-radiation-induced mucositis and its clinical benefits in improving quality of life in patients of oral squamous cell carcinoma. J. Maxillofac. Oral. Surg. 2019, 18, 73-79. [CrossRef]

31. Bansal, A.; Ghoshal, S.; Kumar, B.; Bahl, A. Exploring the role of "Glycerine plus Honey" in delaying chemoradiation induced oral mucositis in head and neck cancers. Int. J. Cancer Ther. Oncol. 2017, 5, 513. [CrossRef] 
32. Das, D.; Agarwal, S.K.; Chandola, H.M. Protective effect of Yashtimadhu (Glycyrrhiza glabra) against side effects of radiation/chemotherapy in head and neck malignancies. Ayu 2011, 32, 196-199. [CrossRef] [PubMed]

33. Najafi, S.; Koujan, S.E.; Manifar, S.; Kharazifard, M.J.; Kidi, S.; Hajheidary, S. Preventive effect of Glycyrrhiza Glabra extract on oral mucositis in patients under head and neck radiotherapy: A randomized clinical trial. J. Dent. 2017, 14, 267-274.

34. Rao, S.; Hegde, S.K.; Rao, P.; Dinkar, C.; Thilakchand, K.R.; George, T.; Baliga-Rao, M.P.; Palatty, P.L.; Baliga, M.S. Honey mitigates radiation-induced oral mucositis in head and neck cancer patients without affecting the tumor response. Foods 2017, 6. [CrossRef] [PubMed]

35. Fogh, S.E.; Deshmukh, S.; Berk, L.B.; Dueck, A.C.; Roof, K.; Yacoub, S.; Gergel, T.; Stephans, K.; Rimner, A.; DeNittis, A.; et al. A randomized phase 2 trial of prophylactic manuka honey for the reduction of chemoradiation therapy-induced esophagitis during the treatment of lung cancer: results of NRG oncology RTOG 1012. Int. J. Radiat. Oncol. Biol. Phys. 2017, 97, 786-796. [CrossRef] [PubMed]

36. Jayalekshmi, J.L.; Lakshmi, R.; Mukerji, A. Honey on oral mucositis: a randomized controlled trial. Gulf J. Oncolog. 2016, 1, 30-37. [PubMed]

37. Samdariya, S.; Lewis, S.; Kauser, H.; Ahmed, I.; Kumar, D. A randomized controlled trial evaluating the role of honey in reducing pain due to radiation induced mucositis in head and neck cancer patients. Indian J. Palliat. Care 2015, 21, 268-273. [CrossRef] [PubMed]

38. Hawley, P.; Hovan, A.; McGahan, C.E.; Saunders, D. A randomized placebo-controlled trial of manuka honey for radiation-induced oral mucositis. Support. Care Cancer 2014, 22, 751-761. [CrossRef]

39. Maiti, P.K.; Ray, A.; Mitra, T.N.; Jana, U.; Bhattacharya, J.; Ganguly, S. The effect of honey on mucositis induced by chemoradiation in head and neck cancer. J. Indian Med, Assoc. 2012, 110, 453-456.

40. Bardy, J.; Molassiotis, A.; Ryder, W.D.; Mais, K.; Sykes, A.; Yap, B.; Lee, L.; Kaczmarski, E.; Slevin, N. A double-blind. placebo-controlled, randomised trial of active manuka honey and standard oral care for radiation-induced oral mucositis. Br. J. Oral Maxillofac. Surg. 2012, 50, 221-226. [CrossRef]

41. Parsons, E.; Begley, A.; Herst, P. Manuka honey mouthwash does not affect oral mucositis in head and neck cancer patients in New Zealand. J. Radiother. Pract. 2012, 11, 249-256. [CrossRef]

42. Rashad, U.M.; Al-Gezawy, S.M.; El-Gezawy, E.; Azzaz, A.N. Honey as topical prophylaxis against radiochemotherapy-induced mucositis in head and neck cancer. J. Laryngol. Otol. 2009, 123, 223-228. [CrossRef] [PubMed]

43. Bucekova, M.; Jardekova, L.; Juricova, V.; Bugarova, V.; Di Marco, G.; Gismondi, A.; Leonardi, D.; Farkasovska, J.; Godocikova, J.; Laho, M.; et al. Antibacterial activity of different blossom honeys: New findings. Molecules 2019, 24, 1573. [CrossRef] [PubMed]

44. Aziz, Z.; Abdul Rasool Hassan, B. The effects of honey compared to silver sulfadiazine for the treatment of burns: A systematic review of randomized controlled trials. Burns 2017, 43, 50-57. [CrossRef] [PubMed]

45. Stephen Haynes, J.; Callaghan, R. Properties of honey: Its mode of action and clinical outcomes. Wounds UK 2011, 7, 50-57.

46. Velikov, P.; Zanev, M. Anwendung von Propolis-Präparaten bei der Behandlung von Radioepitheliitiden nach Telegammatherapie der Pharynxregion. Radiobiol. Radiother. 1989, 30, 363-367.

47. El-Ghazaly, M.A.; Khayyal, M.T. The use of aqueous propolis extract against radiation-induced damage. Drugs Exp. Clin. Res. 1995, 21, 229-236. [PubMed]

48. Javadzadeh Bolouri, A.; Pakfetrat, A.; Tonkaboni, A.; Aledavood, S.A.; Fathi Najafi, M.; Delavarian, Z.; Shakeri, M.T; Mohtashami, A. Preventing and therapeutic effect of propolis in radiotherapy induced mucositis of head and neck cancers: A triple-blind; randomized; placebo-controlled trial. Iran. J. Cancer Prev. 2015, 8, e4019. [CrossRef] [PubMed]

49. Eslami, H.; Pouralibaba, F.; Falsafi, P.; Bohluli, S.; Najati, B.; Negahdari, R.; Ghanizadeh, M. Efficacy of Hypozalix spray and propolis mouthwash for prevention of chemotherapy-induced oral mucositis in leukemic patients: A double-blind randomized clinical trial. J. Dent. Res. Dent. Clin. Dent. Prospect. 2016, 10, 226-233. [CrossRef] [PubMed]

50. Montoro, A.; Almonacid, M.; Serrano, J.; Saiz, M.; Barquinero, J.F.; Barrios, L.; Verdu, G.; Perez, J.; Villaescusa, J.I. Assessment by cytogenetic analysis of the radioprotection properties of propolis extract. Radiat. Prot. Dosim. 2005, 115, 461-464. [CrossRef] [PubMed] 
51. Münstedt, K. Bee products and the treatment of blister-like lesions around the mouth; skin and genitalia caused by herpes viruses-A systematic review. Complement. Ther. Med. 2019, 43, 81-84. [CrossRef]

52. Santiago, K.B.; Piana, G.M.; Conti, B.J.; Cardoso, E.O.; Murbach Teles Andrade, B.F.; Zanutto, M.R.; Mores Rall, V.L.; Fernandes, A., Jr.; Sforcin, J.M. Microbiological control and antibacterial action of a propolis-containing mouthwash and control of dental plaque in humans. Nat. Prod. Res. 2018, 32, 1441-1445. [CrossRef] [PubMed]

53. Tomaževič, T.; Jazbec, J. A double blind randomised placebo-controlled study of propolis (bee glue) effectiveness in the treatment of severe oral mucositis in chemotherapy treated children. Complement. Ther. Med. 2013, 21, 306-312. [CrossRef] [PubMed]

54. AkhavanKarbassi, M.H.; Yazdi, M.F.; Ahadian, H.; SadrAbad, M.J. Randomized double-blind placebo-controlled trial of propolis for oral mucositis in patients receiving chemotherapy for head and neck cancer. Asian Pac. J. Cancer Prev. 2016, 17, 3611-3614.

55. Piredda, M.; Facchinetti, G.; Biagioli, V.; Giannarelli, D.; Armento, G.; Tonini, G.; De Marinis, MG. Propolis in the prevention of oral mucositis in breast cancer patients receiving adjuvant chemotherapy: A pilot randomised controlled trial. Eur. J. Cancer Care (Engl.) 2017, 26, e12757. [CrossRef] [PubMed]

56. Salehi, M.; Saeedi, M.; Ghorbani, A.; Ghodrati, P.; Moosazadeh, M.; Rostamkalaei, S.; Hatkehlouei, M.B.; Molania, T. The effect of propolis tablet on oral mucositis caused by chemotherapy. Gazi Med. J. 2018, 29, 196-201.

57. Watanabe, S.; Suemaru, K.; Takechi, K.; Kaji, H.; Imai, K.; Araki, H. Oral mucosal adhesive films containing royal jelly accelerate recovery from 5-fluorouracil-induced oral mucositis. J. Pharmacol. Sci. 2013, 121, 110-118. [CrossRef] [PubMed]

58. Erdem, O.; Güngörmüş, Z. The effect of royal jelly on oral mucositis in patients undergoing radiotherapy and chemotherapy. Holist. Nurs. Pract. 2014, 28, 242-246. [CrossRef] [PubMed]

59. Yamauchi, K.; Kogashiwa, Y.; Moro, Y.; Kohno, N. The effect of topical application of royal jelly on chemoradiotherapy-induced mucositis in head and neck cancer: A preliminary study. Int. J. Otolaryngol. 2014, 2014, 974967. [CrossRef] [PubMed]

60. Elkerm, Y.; Tawashi, R. Date palm pollen as a preventative intervention in radiation- and chemotherapy-induced oral mucositis: A pilot study. Integr. Cancer Ther. 2014, 13, 468-472. [CrossRef]

61. Seyhan, M.F.; Yılmaz, E.; Timirci-Kahraman, Ö.; Saygılı, N.; Kısakesen, H.İ.; Gazioğlu, S.; Gören, A.C.; Eronat, A.P.; Begüm Ceviz, A.; Öztürk, T.; et al. Different propolis samples; phenolic content; and breast cancer cell lines: Variable cytotoxicity ranging from ineffective to potent. IUBMB Life 2019, 71, 619-631. [CrossRef] [PubMed]

62. Marucci, L.; Farneti, A.; Di Ridolfi, P.; Pinnaro, P.; Pellini, R.; Giannarelli, D.; Vici, P.; Conte, M.; Landoni, V.; Sanguineti, G. Double-blind randomized phase III study comparing a mixture of natural agents versus placebo in the prevention of acute mucositis during chemoradiotherapy for head and neck cancer. Head Neck 2017, 39, 1761-1769. [CrossRef] [PubMed]

63. Liu, T.M.; Luo, Y.W.; Tam, K.W.; Lin, C.C.; Huang, T.W. Prophylactic and therapeutic effects of honey on radiochemotherapy-induced mucositis: A meta-analysis of randomized controlled trials. Support. Care Cancer 2019, 27, 2361-2370. [CrossRef] [PubMed]

64. Yang, C.; Gong, G.; Jin, E.; Han, X.; Zhuo, Y.; Yang, S.; Song, B.; Zhang, Y.; Piao, C. Topical application of honey in the management of chemo/radiotherapy-induced oral mucositis: A systematic review and network meta-analysis. Int. J. Nurs. Stud. 2019, 89, 80-87. [CrossRef] [PubMed]

65. Kuo, C.C.; Wang, R.H.; Wang, H.H.; Li, C.H. Meta-analysis of randomized controlled trials of the efficacy of propolis mouthwash in cancer therapy-induced oral mucositis. Support. Care Cancer 2018, 26, 4001-4009. [CrossRef] [PubMed]

66. Xu, J.L.; Xia, R.; Sun, Z.H.; Sun, L.; Min, X.; Liu, C.; Zhang, H.; Zhu, Y.M. Effects of honey use on the management of radio/chemotherapy-induced mucositis: A meta-analysis of randomized controlled trials. Int. J. Oral. Maxillofac. Surg. 2016, 45, 1618-1625. [CrossRef] [PubMed]

67. Co, J.L.; Mejia, M.B.; Que, J.C.; Dizon, J.M. Effectiveness of honey on radiation-induced oral mucositis; time to mucositis; weight loss; and treatment interruptions among patients with head and neck malignancies: A meta-analysis and systematic review of literature. Head Neck 2016, 38, 1119-1128. [CrossRef]

68. Cho, H.K.; Jeong, Y.M.; Lee, H.S.; Lee, Y.J.; Hwang, S.H. Effects of honey on oral mucositis in patients with head and neck cancer: A meta-analysis. Laryngoscope 2015, 125, 2085-2092. [CrossRef] [PubMed] 
69. Münstedt, K. Topical application of honey in the management of chemo/radiotherapy-induced oral mucositis: Comment on Yang et al.; 2019. Int. J. Nurs. Stud. 2019, 92, 57. [CrossRef] [PubMed]

70. Scheller, S.; Krol, W.; Swiacik, J.; Owczarek, S.; Gabrys, S.; Shani, J. Antitumoral property of ethanolic extract of propolis in mice bearing Ehrlich carcinoma; as compared to bleomycin. Z. Naturforsch. C 1989, 44, 1063-1065. [CrossRef]

71. Chopra, S.; Pillai, K.K.; Husain, S.Z.; Giri, D.K. Propolis protects against doxorubicin-induced myocardiopathy in rats. Exp. Mol. Pathol. 1995, 62, 190-198. [CrossRef] [PubMed]

(C) 2019 by the authors. Licensee MDPI, Basel, Switzerland. This article is an open access article distributed under the terms and conditions of the Creative Commons Attribution (CC BY) license (http://creativecommons.org/licenses/by/4.0/). 